RESEARCH NOTE

\section{Feeding Preference of the Larvae of Chrysomya megacephala (Fabricius) (Diptera: Calliphoridae) and Ravinia belforti (Prado e Fonseca) (Diptera: Sarcophagidae) Concerning Different Diets}

\section{José Mario d'Almeida, Ricardo José Barbosa Salviano}

Laboratório de Biologia e Controle de Insetos

Vetores, Departamento de Biologia, Instituto

Oswaldo Cruz, Av. Brasil 4365, 21045-900 Rio de

Janeiro, RJ, Brasil

Key words: larvae preference - flies - diets

Laboratory studies have shown that larvae of certain insect species can choose their rearing substrate from a nutritional viewpoint (HL House 1967 Can Ent 99: 1310-1321, S Ishikawa et al. 1969 Ent Exp Appl 12: 544-554). According to FS Zucoloto 1987 (J Insect Physiol 33: 245-353), the larvae of fruit flies have receptors which draw them to particular types of food and enable them to identify the best diets, that is, diets that contain a larger amount of protein.

Due to the pausity of studies on the feeding habits of larval caliptrate diptera, we developed this study. Two synanthropic flies have been used as models: Chrysomya megacephala (Townsend, 1935) and Ravinia belforti (Prado \& Fonseca, 1932). The aim of this research was to evaluate whether newly hatched larvae are able to select different diets in laboratory conditions.

The free choice experiments were carried out with flies being colonized so that replicates were of different generations. Twenty two laboratory replicate tests with C. megacephala were done (two tests with the 5th generation larvae, four with the 6th, seven with the 8th, seven with the 9th, and two with the 11th generation), and eight tests with $R$. belforti (two with the larvae of the 3rd genera-

Received 3 May 1995

Accepted 18 October 1995 tion, two with the 4th, three with the 5th, and one with the 6th generation).

The tests were done in a $15 \mathrm{~cm}$ diameter Petri dish containing a layer of $1 \mathrm{~cm}$ of pure agar $(2 \mathrm{~g}$ for $20 \mathrm{ml}$ of water) so the larvae could move. Nine $2 \mathrm{~cm}$ circular holes, were opened in the agar eight being equally distant from the central hole (Fig.). We dropped melted agar in the newly opened holes, which after getting cold, formed a thin layer that sealed the space between the glass and the agar. Thus, preventing the larvae from escaping from the hole under the agar layer.

In the four holes indicated by letter "A" (Fig.) were placed the diets to be tested (mashed fish, minced meat with $24 \mathrm{hr}$ of environmental exposure, recent human faeces and mashed aged banana). The holes " $\mathrm{B}$ " remained empty and in the central hole designated as " $\mathrm{C}$ " recently hatched larvae were placed. For each test a newly prepared Petri dish was used.

The testing dishes with the larvae of $C$. megacephala and $R$. belforti were kept in a chamber with temperature of $27^{\circ} \mathrm{C}, 80 \pm 10 \% \mathrm{UR}$, for a period of $6 \mathrm{hr}$. Afterwards, the larvae were counted in each hole containing the diets. The experiments were carried out from May to October 1993.

The results obtained were statistically analyzed through the adherence test of $\chi^{2}$ at $1 \%$ probability.

The Table shows that $69 \%$ of the larvae of $C$. megacephala and $47 \%$ of the $R$. belforti were found in the holes containing mashed fish, indicating that this particular diet is highly attractant to the larvae of these flies.

It has been demonstrated that adult flies of $C$. megacephala are attracted to fish. It has been proved not only by faunistic surveys (AX Linhares 1981 Rev Bras Entomol 25: 189-215, JM d'Almeida, HS Lopes 1983 Arq Univ Fed Rur Rio de $J$ 6: 38-48), but also in studies about the preference for ovipositional substrates. In addition, meat is an attractive diet for the C. megacephala larvae but less attractive than fish (Table ).

The larvae of $C$. megacephala were not attracted to faeces or banana $(1.2 \%$ and $0.5 \%$ respectively). When these diets were used as baits to attract flies and as ovipositional substrates, they proved to be ineffective (d'Almeida, Lopes 1983 loc. cit., JM d'Almeida 1988 Mem Inst Oswaldo Cruz 83: 201-206). Nevertheless, KR Norris 1965 (Ann Rev Entomol 10: 47-68) reports that faeces is a good environment for rearing C. megacephala.

The Sarcophagidae $R$. belforti, is frequently bred in human and animal faeces (JM d'Almeida 1989 Mem Inst Oswaldo Cruz 84: 257-264, HS 
Lopes 1973 An Acad Bras Ciênc 45: 279-291).The experiment showed that although the larvae often go towards faeces, they were more attracted to mashed fish (Table). The aged banana proved to be of little attractancy.

The results suggest that further experiments are required, breeding flies with different diets for several generations to test whether factors can induce larvae to choose different foods from those that are more frequently attractive to female flies to lay eggs or larvae.

Studies on the nutritional behavior and oviposition are advance to the knowledgment of ecological and evolutive relationship of insects that involve physiologycal aspects such as distinct distribution of chemioreceptors in adults and larvae.

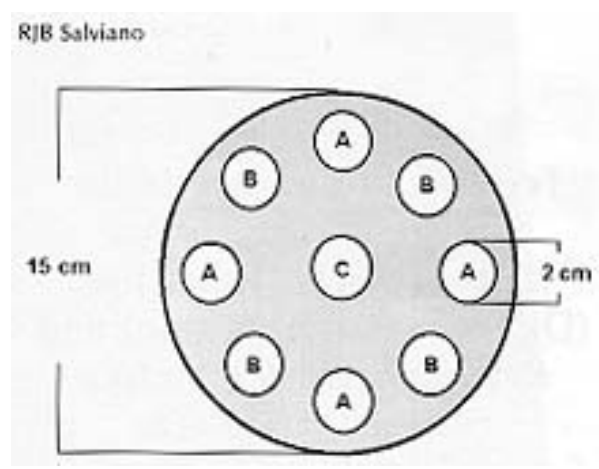

Experimental dish with agar to test the larval choice for diets concerning both species: C. megacephala and R. belforti (A: holes with the diets, B: empty holes and C: hole with newly hatched larvae).

\section{TABLE}

Distribution of larvae of Chrysomya megacephala and Ravinia belforti among different diets, under controlled laboratory conditions $\left(27^{\circ} \mathrm{C}, 80 \pm 10 \% \mathrm{UR}\right)$

\begin{tabular}{|c|c|c|c|c|c|c|c|c|c|c|c|c|}
\hline \multirow{3}{*}{ Species } & \multicolumn{12}{|c|}{$\begin{array}{c}\text { Variables } \\
\text { Larvae }\end{array}$} \\
\hline & \multicolumn{2}{|c|}{ Total } & \multicolumn{2}{|c|}{ Free } & \multicolumn{2}{|c|}{ Fish } & \multicolumn{2}{|c|}{ Meat } & \multicolumn{2}{|c|}{ Faeces } & \multicolumn{2}{|c|}{ Banana } \\
\hline & No. & $\%$ & No. & $\%$ & No. & $\%$ & No. & $\%$ & No. & $\%$ & No. & $\%$ \\
\hline C. megacephala & 3387 & 100 & 316 & 9.3 & $2337 a^{*}$ & 69.0 & $675 b$ & 19.9 & $41 c$ & 1.2 & $18 \mathrm{~d}$ & 0.5 \\
\hline$R$. belforti & 951 & 100 & 71 & 7.5 & $447 a^{*}$ & 47.0 & $174 \mathrm{c}$ & 18.3 & $243 b$ & 25.5 & $16 \mathrm{~d}$ & 1.7 \\
\hline
\end{tabular}

* These values, in decreasing order, followed by the same letter don't have significant difference at $1 \%$ probability (Chi-square test). 